Jurnal TEKNOSIA

Vol. 1 No. 1, Bulan Juni 2021, Hal: $7-15$

https://ejournal.unib.ac.id/index.php/teknosia

P-ISSN No. : 1978-8819

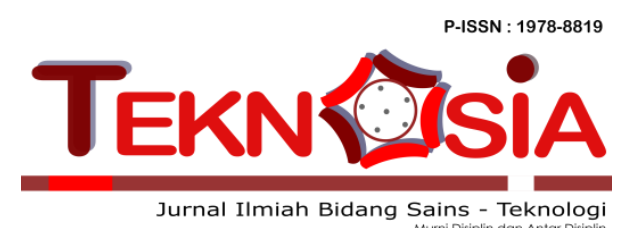

\title{
FINITE ELEMENT ANALYSIS PADA DINDING PENAHAN TANAH SIMPANG UNDERPASS UNIVERSITAS LAMPUNG
}

\author{
Putri Indah Sahfitri', Fikri Alami', Iswan ${ }^{1}$
}

1 Jurusan Teknik Sipil, Fakultas Teknik Universitas Lampung

E-mail : pindah130@gmail.com, fikri.alami@eng.unila.ac.id, syahiswan72@gmail.com

Informasi Naskah:

Diterima:

1 April 2021

Diterbitkan:

3 Juni 2021

\begin{abstract}
Retaining Wall that serves to withstand loose or natural soil and prevent the collapse of sloping soil or slopes whose stability can not be guaranteed by the slope of the land itself. This study was to analyze deformation behaviour occurred on the earth retaining wall on Underpass Project University of Lampung from STA 0+80 to 0+140 using Finite Element Analysis (FEA)method.

Cantilever retaining wall as high as $5.27 \mathrm{~m}$ located on STA 0+140 selected at this modelling. This wall was to resist vertical forces above it and horizontal forces behind the wall. The effect of earthquake loads was also included in the analysis. The results shoewed that the wall was safe against the working forces with a safety factor of 1.351 (greater than 1.25 as minimum requirement) with a total deformation that occured due to lane loads and earthquake loads of 1.43 meters.
\end{abstract}

Keywords : Earth Retaining Wall, deformation, Finite Element Analysis.

Abstrak: Dinding Penahan Tanah yang berfungsi untuk menahan tanah lepas atau alami dan mencegah keruntuhan tanah yang miring atau lereng yang kemantapannya tidak dapat dijamin oleh lereng tanah itu sendiri. Studi ini menganalisis perilaku deformasi yang terjadi pada dinding penahan tanah Proyek Underpass Universitas Lampung dari STA 0+80 s/d 0+140 dengan menggunakan metode Finite Element Analysis (FEA). Dinding penahan tanah kantilever setinggi 5,27m pada STA 0+140 dipilih pada pemodelan ini. Dinding berfungsi untuk menahan gaya-gaya vertikal di atasnya dan gaya horizontal dibelakang dinding. Pengaruh beban gempa juga dimasukkan dalam analisis. Hasil menunjukkan bawah dinding aman terhadap gaya-gaya yang bekerja dengan faktor keamanan sebesar 1,351 (lebih besar dari 1,25 sebagai syarat minimum) dengan total deformasi yang terjadi akibat beban lajur dan beban gempa sebesar 1,43 meter.

Kata kunci : Dinding Penahan Tanah, Deformasi, Finite Element Analysis.

\section{PENDAHULUAN}

Dinding

merupakan

penahan

konstruksi

tanah

dengan

kemiringan atau lereng yang dibangun

untuk menahan tanah dimana

kemantapan tanah tidak dapat dijamin oleh tanah itu sendiri. Bangunan ini digunakan untuk menahan tekanan tanah lateral yang ditimbulkan oleh tanah urugan atau tanah asli yang labil akibat kondisi topografinya (Setiawan, $2011)$. 
Dinding penahan tanah pada prinsipnya menerima gaya-gaya seperti momen guling, gaya berat sendiri, gaya lateral tanah/air aktif-pasif, gaya geser (sliding), gaya angkat (uplift) dan beban gempa. Kestabilan konstruksi dinding penahan harus dirancang agar dapat menahan gaya-gaya tersebut. Konstruksi penahan tanah ini dapat dikatakan aman apabila telah diperhitungkan faktor keamanannya, baik terhadap bahaya pergeseran, bahaya penggulingan, dan penurunan daya dukung tanah. Studi ini membahas dinding penahan tanah kantilever dengan ketinggian 2,5 m-6,0 $\mathrm{m}$ menggunakan metode Finite Elemen Analysis (FEA). Studi Ini diambil dari proyek underpass Universitas Lampung pada STA. $0+140$ dengan tinggi 5,27 meter. Perilaku deformasi, tegangan efektif dan faktor keamanan menjadi outcome dari studi ini .

\section{TINJAUAN PUSTAKA}

\section{Dinding Penahan Tanah}

Dinding penahan tanah adalah bangunan yang berfungsi menstabilkan tanah pada kondisi tanah tertentu khususnya untuk areal lereng alam dan lereng buatan serta lereng akibat urugan tanah. Ketika kondisi tanah terganggu akibat beberapa hal tertentu, seperti beban gempa, beban getaran mesin, peledakan, air tanah dan lain-lain yang dapat menurunkan sifat fisik dan sifat mekanik dari parameter tanah, akan terjadi kerusakan struktur dan membahayakan jiwa manusia. Untuk meminimalisir kondisi tersebut, harus di desain kestabilan dari struktur dinding penahan tanah tersebut agar mampu menahan beban dari tanah dan pengaruh beban luar (Kalalo, Ticoh, \& Mandagi, 2017).

Posisi tanah yang tertahan atau miring bisa memberikan gaya dorong pada struktur dinding, sehingga struktur cenderung akan bergeser atau terguling. Salah satu metode untuk memodelkan bentuk dan geometri tanah yang bervariasi adalah dengan metode elemen hingga (Sabina \& Makarim, 2020). Aplikasi metode elemen hingga yang diterapkan pada pemodelan dinding penahan tanah dapat dilihat pada artikel (Winanda, Setyanto, \& Hadi, 2017).

\section{Dinding Penahan Tanah Kantilever}

Jenis konstruksi dinding penahan tanah kantilever umumnya digunakan untuk menahan tekanan tanah pada timbunan maupun pada tebing. Prinsip kerja dari jenis dinding penahan jenis ini yaitu dengan mengandalkan daya jepit pada dasar tubuh strukturnya. Oleh karena itu ciri khas dari dinding penahan jenis kantilever yaitu berupa model telapak memanjang pada dasar strukturnya yang bersifat jepit untuk menjaga kestabilan dari struktur penahan. Umumnya konstruksi dinding penahan tipe jepit dibuat dari pasangan batu maupun dengan konstruksi beton bertulang.

\section{Tekanan Tanah Lateral}

Tekanan tanah lateral adalah sebuah parameter perencanaan penting di dalam sejumlah persoalan teknik pondasi, dinding penahan dan konstruksi-konstruksi lain yang ada di bawah tanah (Linda Tamaela, Suhudi, 2018). Tekanan lateral tanah ini yang menyebabkan timbulnya gaya horizontal pada dinding penahan tanah, sehingga dapat menyebabkan terjadinya deformasi pada dinding penahan tanah. Tekanan lateral tanah adalah besarnya gaya yang timbul akibat dorongan dari belakang struktur penahan tanah. Tekanan tanah lateral ini disebabkan oleh letak dari dinding 
penahan tanah dan jenis tanah sekitar dinding penahan tanah (Sabina \& Makarim, 2020).

\section{Stabilitas Dinding Penahan Tanah}

Tekanan tanah dan gaya-gaya yang bekerja pada dinding penahan tanah sangat mempengaruhi stabilitas dinding penahan tanah itu sendiri, secara umum pemampatan atau penggunaan bahan dalam konstruksi dinding penahan tanah yang berarti memberikan perkuatan pada massa tanah, memperbesar timbunan di belakang dinding penahan tanah. Perkuatan ini, juga mengurangi potensi gaya lateral yang menimbulkan perpindahan kearah horisontal dari pada dinding tersebut sebagai akibat adanya beban vertikal yang dipindahkan menjadi tekanan horizontal yang bekerja dibelakang dinding penahan tanah atau biasa dikenal sebagai tekanan tanah aktif (Suryolelono, 1994).

Untuk mengetahui stabilitas dinding penahan tanah kantilever, perlu dilakukan pengecekan terhadap dinding kantilever tersebut (Hakam \& Mulya, 2011).

\section{Finite Element Analysis (FEA)}

Teknologi di bidang konstruksi bangunan mengalami perkembangan pesat, termasuk teknologi dalam bidang geoteknik. Sudah banyak diketahui bersama bahwa untuk mempercepat dalam perhitungan dan meminimalisir kesalahan pada saat menghitung kestabilan dinding penahan tanah dengan menggunakan finite element analysis (FEA) (George R. Buchanan, 1994).

Finite Element Analysis (FEA) adalah metode untuk solusi numerik dari persamaan diferensial.
Solusi numerik atau metode elemen hingga merupakan salah satu metode yang tepat untuk mengetahui perilaku baik linier maupun sampai tahap nonlinear terhadap struktur dinding geser beton bertulang. Konsep dasar metode elemen hingga adalah struktur kontinum ditinjau sebagai rangkaian elemen-elemen kecil yang terhubung dengan titik-titik nodal (node) yang terdapat pada tepi-tepi elemen. Setiap elemen mempunyai beberapa titik nodal dan masing-masing titik nodal mempunyai beberapa derajat kebebasan (degree of freedom) (Dewi, Zacoeb, \& Brawijaya, 2017).

Metode elemen hingga adalah metode numerik yang digunakan untuk menyelesaikan permasalahan teknik dan metematis dari suatu gejala phisis yang diantaranya adalah tegangan, regangan, kekuatan, dan analisa getaran (Mulyadi, 2011).

\section{METODE PENELITIAN Lokasi Penelitian}

Lokasi penelitian ini berada di jalan Zainal Abidin Pagar Alam, tepatnya di awal jalan masuk Universitas Lampung yaitu jalan Prof. Dr. Soemantri Brojonegoro Bandar Lampung.

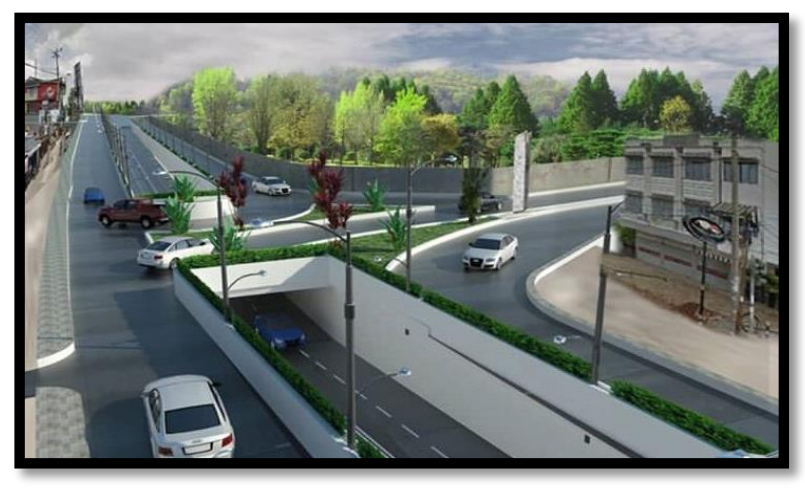

Gambar 1. Lokasi Penelitian

Gambar potongan melintang pada dinding penahan tanah yang ditinjau dapat dilihat pada Gambar 2. 


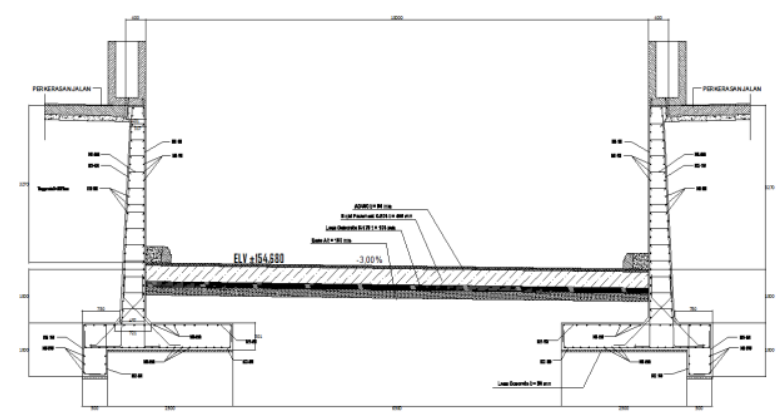

Gambar 2. Tampak Melintang STA 0+080 $0+140$

\section{Metode Penelitian}

Penelitian ini menggunakan metode numerik (finite element analysis) dalam pemodelan struktur dinding penahan tanah dan tanah disekitarnya.

Tahapan analisis dinding penahan tanah dengan menggunakan FEA :

\section{Pembuatan Model Geometri}

Dalam pembuatan model geometri, masukan (input) berupa pelapisan tanah, elemen-elemen struktur, tahapan konstruksi, pembebanan serta kondisi-kondisi batas dilakukan dengan menggunakan prosedur grafis yang memungkinkan pembuatan model geometri berupa penampang melintang yang mendetail.

\section{Pembuatan Model Material}

Dalam pembuatan model material, material tersebut di modelkan dari pengguna dengan data-data sekunder yang diberikan oleh proyek tersebut.

\section{Penyusunan Jaring Elemen}

Setelah model geometri didefinisikan secara lengkap dan sifat material telah diaplikasikan ke seluruh klaster dan objek struktural, maka geometri harus dibagibagi menjadi elemenelemen untuk melakukan perhitungan elemen hingga. Jaring elemen di buat secara otomatis oleh plaxis dengan pilihan untuk memperhalus jaring elemen secara global maupun lokal. Semakin halus jaring elemen yang dibuat, semakin akurat hasil yang didapatkan dalam analisis tersebut.

\section{Kondisi Awal}

Setelah model geometri terbentuk dan jaringan elemen disusun, kondisi tegangan awal dan konfigurasi awal harus ditentukan terlebih dahulu. Garis freatik tidak diperhitungkan karena muka air tanah berada jauh dibawah tanah. Oleh karena itu, langsung ke tahap perhitungan (calculation).

\section{Perhitungan}

Setelah penyusunan model elemen hingga, perhitungan elemen hingga sesungguhnya dapat dilakukan. Karena itu, perlu untuk mendefinisikan jenis perhitungan yang akan dilakukan dan jenis pembebanan atau tahapan konstruksi mana saja yang akan di aktifkan dalam perhitungan. Dalam penelitian ini untuk perhitungan di bedakan dari jenis pembebanan yang akan melakukan analisis deformasi.

6. Keluaran

Keluaran (output) dapat dibuka kembali dengan klik toolbar output, atau dari start menu. Toolbar calculation pada calculation program dapat juga dipakai untuk masuk ke output program, jika input telah selesai dan telah memilih titik yang akan ditinjau.

Selain melihat perpindahan tegangan yang terjadi didalam tanah, output program dapat digunakan untuk melihat gaya-gaya yang bekerja pada objek structural. Untuk menampilkan hasil yang diperoleh dari hasil analisis ini adalah sebagai berikut :

a. Pilih menu peningkatan total dari menu deformasi. Tampilan akan menunjukkan peningkatan dari 
seluruh titik nodal dalam bentuk anak panah. Panjang dari anak panah menunjukkan nilai relatifnya.

b. Pilih tegangan efektif dari menu tegangan. Tampilan akan menunjukkan besar dan arah dari tegangan-tegangan utama efektif.

\section{Data Analisis dan Desain}

Pengumpulan data pada penelitian ini hanya menggunakan data-data sekunder seperti shop drawing, data properties tanah, dan data pendukung lainnya yang didapat dari Dinas
Pekerjaan Umum Kota Bandar Lampung.

\section{HASIL PENELITIAN DAN PEMBAHASAN Data Dinding Penahan Tanah}

Data potongan melintang dari struktur dinding penahan tanah sesuai dengan kondisi struktur dinding penahan tanah dilapangan. Spesikasi struktur dinding penahan tanah adalah sebagai berikut.

1. Dinding penahan tanah terbuat dari beton bertulang

2. Mutu beton bertulang yang digunakan adalah K-300.

3. Berat volume beton bertulang yang digunakan adalah $2,4 \mathrm{~T} / \mathrm{m}^{3}$.

4. Dinding penahan tanah memiliki jenis tipe dinding kantilever.

Tabel 1. Parameter Tanah

\begin{tabular}{cccccc}
\hline Parameter & Notasi & Satuan & Tanah 1 & Tanah 2 & Tanah 3 \\
\hline $\begin{array}{c}\text { Model } \\
\text { Material }\end{array}$ & Model & - & $\begin{array}{c}\text { Mohr- } \\
\text { Coloumb }\end{array}$ & $\begin{array}{c}\text { Mohr- } \\
\text { Coloumb }\end{array}$ & $\begin{array}{c}\text { Mohr- } \\
\text { Coloumb }\end{array}$ \\
\hline $\begin{array}{c}\text { Jenis Perilaku } \\
\text { Material }\end{array}$ & Jenis & - & Terdrainase & $\begin{array}{c}\text { Tak } \\
\text { Terdrainase }\end{array}$ & $\begin{array}{c}\text { Tak } \\
\text { Terdrainase }\end{array}$ \\
\hline $\begin{array}{c}\text { Berat Volume } \\
\text { Unsaturated }\end{array}$ & $\gamma_{\text {unsat }}$ & $\mathrm{kN} / \mathrm{m}^{3}$ & 17 & 16 & 17 \\
\hline $\begin{array}{c}\text { Berat Volume } \\
\text { Saturated }\end{array}$ & $\gamma_{\text {sat }}$ & $\mathrm{kN} / \mathrm{m}^{3}$ & 20 & 18 & 19 \\
\hline \begin{tabular}{c} 
Permeabilitas \\
\cline { 2 - 6 }
\end{tabular} & $K_{x}$ & $\mathrm{~m} / \mathrm{hari}$ & 1 & 0.001 & 0.001 \\
\hline $\begin{array}{c}\text { Modulus } \\
\text { Elastisitas }\end{array}$ & $\mathrm{K} / \mathrm{hari}$ & $\mathrm{kN} / \mathrm{m}^{2}$ & 19000 & 10000 & 15000 \\
\hline $\begin{array}{c}\text { Angka } \\
\text { Poisson }\end{array}$ & $v$ & - & 0.2 & 0.2 & 0.2 \\
\hline Kohesi & $\mathrm{C}$ & $\mathrm{kN} / \mathrm{m}^{2}$ & 0.0001 & 10 & 20 \\
\hline $\begin{array}{c}\text { Sudut Geser } \\
\text { Dalam }\end{array}$ & $\emptyset$ & $\circ$ & 30 & 18 & 20 \\
\hline
\end{tabular}

\section{Input Parameter Bangunan}

Material bangunan yang dimodelkan adalah dinding penahan tanah yang dimana keberadaan material terbuat dari beton bertulang dengan mutu beton k-300 yang merupakan model eksisting yang akan dianalisis deformasinya karena pengaruhnya dapat berupa beban maupun perkuatan lereng. Parameterparameter bangunan dinding penahan tanah dapat dilihat pada Tabel 2. 
Tabel 2. Parameter Bangunan Dinding Penahan Tanah

\begin{tabular}{cccc}
\hline Parameter & Notasi & Satuan & Nilai \\
\hline Model Material & Model & - & Linier - Elastic \\
\hline Jenis Perilaku Material & Jenis & $(\mathrm{kN} / \mathrm{m})$ & Non - Porous \\
\hline Berat Volume Beton & $\gamma_{\text {beton }}$ & $\left(\mathrm{kN} / \mathrm{m}^{3}\right)$ & 24 \\
\hline Modulus Elastisitas & $E$ & $\left(\mathrm{kN} / \mathrm{m}^{2}\right)$ & 23025200 \\
\hline Angka Poisson & $v$ & - & 0,2 \\
\hline
\end{tabular}

\section{Input Parameter Pembebanan}

Setelah input parameter tanah, beban yang bekerja pada dinding penahan tanah setelah operasional adalah beban lajur yang diasumsikan sebagai beban merata. Dalam hal ini beban yang direncanakan untuk menganalisis perilaku deformasi yang terjadi pada struktur dinding penahan tanah diasumsikan menjadi 2 pembebanan, yaitu beban lajur atas $\left(9,44 \mathrm{kN} / \mathrm{m}^{2}\right)$ dan beban lajur bawah $\left(22,76 \mathrm{kN} / \mathrm{m}^{2}\right)$. Selain beban lajur, untuk model akibat beban dinamis yaitu beban gempa juga diterapkan pada penelitian ini. Beban gempa pada model diaktifkan seperti pada analisis statis. Data yang digunakan dalam analisis dinamis pada model ini berupa akselerogram dalam format SMC (Strong Motion CD-ROM) yang sebagian besar berisi data percepatan gempa. Percepatan yang digunakan berupa data akselerogram dengan PGA $388,50 \mathrm{~cm} / \mathrm{s}^{2}$ atau $0,396 \mathrm{~g}$ karena data gempa tersebut memasuki areal yang sesuai dengan peta zonasi gempa yang dikeluarkan oleh kementerian pekerjaan umum yang dapat dilihat pada Gambar 4. Percepatan gempa ini dianggap sesuai dengan percepatan puncak di lokasi penelitian berdasarkan peta gempa yang dikeluarkan oleh Departemen Pekerjaan Umum Republik Indonesia. Peta ini menempatkan Bandar Lampung dan sekitarnya dalam zona koefisien gempa 0,3-0,4g yang dapat dilihat pada Gambar 3.

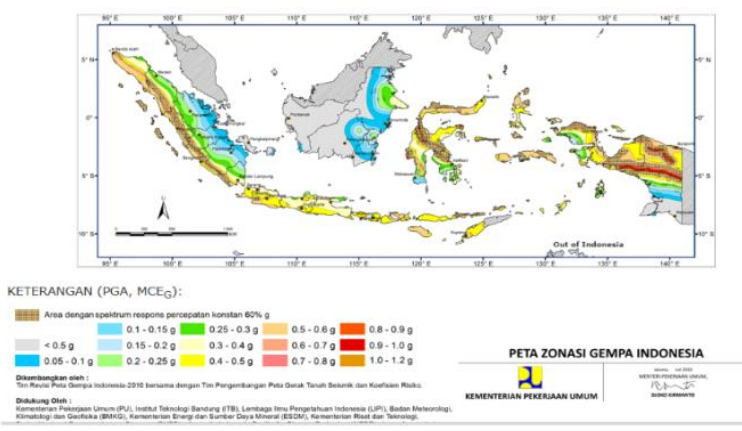

Gambar 3. Peta Zonasi Gempa Indonesia (Sumber: Kementerian Pekerjaan Umum, 2010)

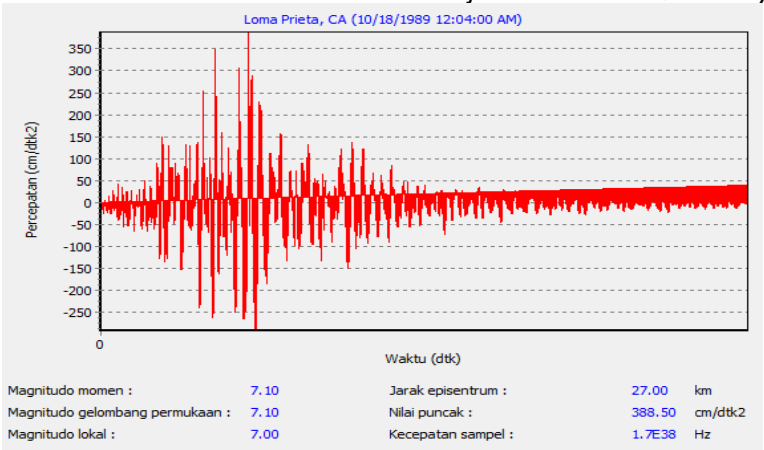

Gambar 4. Grafik Hubungan Antara Percepatan Gempa dan Waktu Gempa Wilayah Loma Prieta, California, 18 Oktober 1989

\section{Hasil Perhitungan Software}

Setelah seluruh rangkaian perhitungan selesai, maka hasil perhitungan dapat ditentukan nilainya. Dalam penelitian ini, hasil perhitungan yang ditinjau adalah deformasi dari dinding penahan tanah dari potongan melintang yang ditentukan berdasarkan nilai displacement struktur tersebut.

1. Analisis akibat beban lajur

Untuk hasil jaring-jaring elemen hingga (meshing) pada STA. 0+140 dengan deformed mesh beban lajur. Deformasi yang terjadi sebesar $613,2 \times 10^{-3} \mathrm{~m}$, semakin besar nilai deformasi maka 
kemungkinan terjadi kelongsoran semakin besar akibat deformasi tanah yang terjadi secara vertikal maupun horizontal. Besarnya deformasi yang terjadi dipengaruhi oleh besarnya sudut kemiringan tanah lajur bawah juga beban pada lajur atas dan lajur bawah.

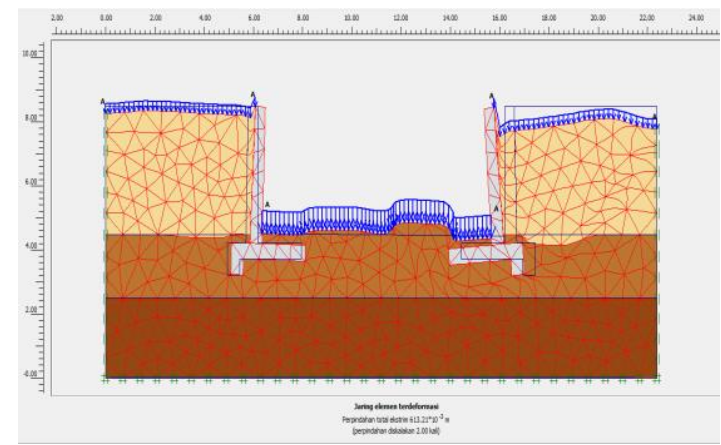

Gambar 5. Deformed Mesh dengan Beban Lajur

Besarnya nilai effective stresses dengan beban merata lajur adalah sebesar 176,56 kN/m². Tegangan efektif berpengaruh terhadap kuat geser dan perubahan volume atau penurunan tanah yang terjadi pada tanah. Semakin dalam tanah maka tegangan efektif tanah yang terjadi akan semakin besar, hal ini ditunjukan oleh elemen kerapatan elemen merah yang berada pada tanah, semakin rapat elemen maka tegangan efektif tanah yang terjadi semakin besar.

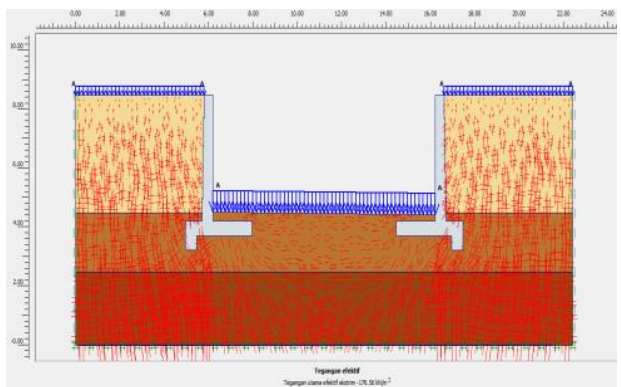

Gambar 6. Effective Stresses dengan Beban Lajur

Besarnya nilai total displacement dengan beban lajur adalah sebesar $0,6132 \mathrm{~m}$. Beban lajur diasumsikan sebagai beban merata dengan panjang sesuai dengan lebar jalan dilokasi penelitian.

2. Analisis Akibat Beban Lajur dan Beban Gempa

Untuk hasil jaring-jaring elemen hingga (meshing) pada STA. 0+140 dengan deformed mesh beban lajur dan beban gempa. Deformasi yang terjadi sebesar 1430 $\times 10^{-3} \mathrm{~m}$, semakin besar nilai deformasi maka kemungkinan terjadi kelongsoran semakin besar akibat deformasi tanah yang terjadi secara vertikal maupun horizontal.

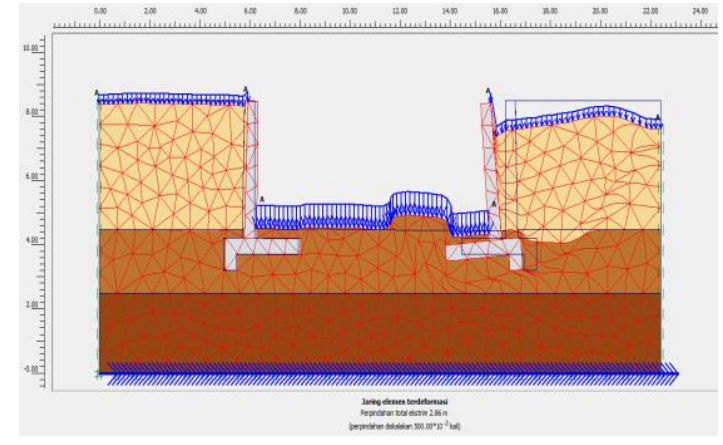

Gambar 7. Deformed Mesh dengan Beban Lajur dan Beban Gempa

Besarnya deformasi yang terjadi dipengaruhi oleh besarnya sudut kemiringan tanah lajur bawah juga beban pada lajur atas dan lajur bawah. Besarnya nilai effective stresses dengan beban merata lajur dan beban gempa adalah sebesar - 176,52 $\mathrm{kN} / \mathrm{m}^{2}$. Besarnya nilai total displacement dengan beban lajur dan beban gempa adalah sebesar 1,43m.

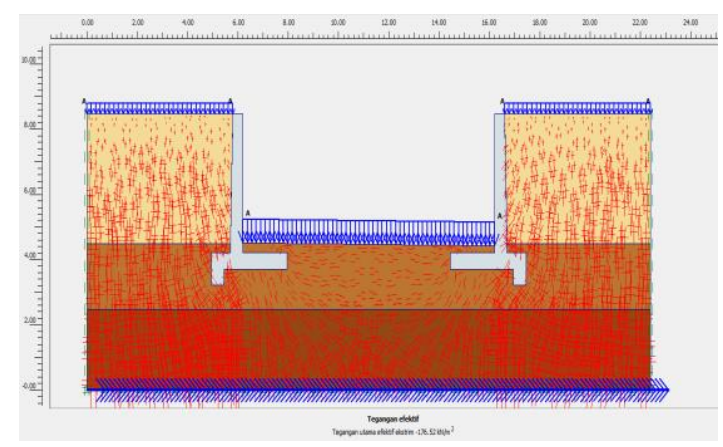

Gambar 8. Effective Stresses dengan Beban Lajur dan Beban Gempa

P-ISSN No. : 1978-8819 
Beban lajur diasumsikan sebagai beban merata dengan panjang sesuai dengan lebar jalan dilokasi penelitian.

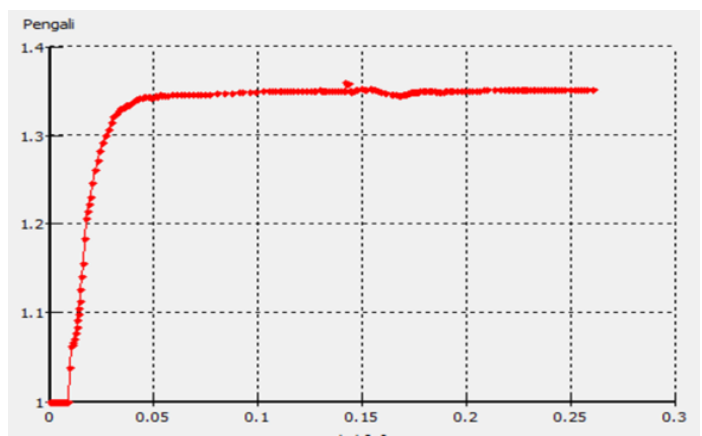

Gambar 9. Tampilan Kurva Faktor Aman Hasil iterasi yang dilakukan memiliki nilai faktor aman sebesar $F s=1,351$, nilai ini sudah memenuhi dan dapat dikatakan aman.

\section{KESIMPULAN}

Dari hasil analisis dapat disimpulkan sebagai berikut :

1. Deformasi dinding penahan tanah sebelah kanan lebih dominan dibandingkan yang kiri dalam pemodelan, dikarenakan bagian lantai kendaraan turun $3 \%$ dari kiri ke kanan yang menyebabkan tekanan tanah pasif sebelah kanan lebih kecil. Dengan bekerjanya gaya gempa dari kiri ke kanan akan terjadi deformasi yang tidak simetris.

2. Perilaku deformasi yang terjadi pada massa tanah dinding penahan tanah kantilever setinggi 5,27m berada di STA. 0+140 yang dianalisis, diperoleh nilai faktor aman (Fs) adalah sebesar 1,351 dan dapat dikatakan aman atau berada pada posisi stabil (Fs > 1,25) sesuai dengan ketentuan pada program.

3. Nilai perpindahan total beban lajur tanpa beban gempa sebesar $0,6132 \mathrm{~m}$ dan besarnya nilai effective stresses adalah sebesar -176,56 kN/m² dan dengan beban gempa sebesar $1,43 \mathrm{~m}$ dan besarnya nilai effective stresses adalah sebesar $-176,52 \mathrm{kN} / \mathrm{m}^{2}$.

\section{DAFTAR PUSTAKA}

Dewi, S. M., Zacoeb, A., \& Brawijaya, U. (2017). Analisa Non - Linier Dengan Pendekatan Smeared Crack Dan Smeared Element Menggunakan Metode. III(167), 179-189.

George R. Buchanan. (1994). Finite Element Analysis. McGraw-Hill, New York.

Hakam, A., \& Mulya, R. P. (2011). Studi Stabilitas Dinding Penahan Tanah Kantilever Pada Ruas Jalan Silaing Padang - Bukittinggi Km 64+500. Jurnal Rekayasa Sipil (JRS-Unand), 7(1), 57. https://doi.org/10.25077/jrs.7.1.5774.2011

Kalalo, M., Ticoh, J. H., \& Mandagi, A. T. (2017). Analisis Stabilitas Dinding Penahan Tanah (Studi Kasus: Sekitar Areal PT. Trakindo, Desa Maumbi, Kabupaten Minahasa Utara). Jurnal Sipil Statik, 5(5), 285-294.

Linda Tamaela, Suhudi, A. K. A. (2018). Analisis Stabilitas Dinding Penahan Tanah di Perumahan Pegawai Negeri Sipil Kepanjen Kabupaten Malang. Jurnal Penelitian Mahasiswa Teknik Sipil Dan Teknik Kimia, 2(2), 295-301.

Mulyadi, S. (2011). Analisa TeganganRegangan Produk Tongkat Lansia Dengan Menggunakan Metode Elemen Hingga. Jurnal ROTOR, $4,1$.

Sabina, N., \& Makarim, C. A. (2020). Proses Analisa Dinding Galian Basement 7 Lantai Dengan Metode Elemen Hingga. JMTS: Jurnal Mitra Teknik Sipil, 3(1), 49. https://doi.org/10.24912/jmts.v3i1.6980

Setiawan, H. (2011). Perbandingan Penggunaan Dinding Penahan Tanah Tipe Kantilever Dan Gravitasi Dengan Variasi Ketinggian Lereng. Journal Teknik Sipil Dan Infrastruktur, 1 (2), 8895. Retrieved from http://jurnal.untad.ac.id/jurnal/index.p $\mathrm{hp} / \mathrm{JTSI} /$ article/view/687 
Suryolelono, K. B. (1994). Teknik Pondasi Bagian 1 (Pondasi telapak dan dinding penahan tanah). Yogyakarta: Universitas Gajah Mada.

Winanda, R. A., Setyanto, \& Hadi, Y. M. (2017). Perencanaan Dinding Penahan Tanah Concrete Cantilever Dengan Menggunakan Program Plaxis. Jrsdd, 5(4), 1-13. 